\title{
Investigation on microstructure and mechanical properties of short-carbon-fiber/Ti3SiC2 composites
}

Guangqi He ( $\sim$ hegq0727@163.com )

northeastern university https://orcid.org/0000-0001-9700-8209

Rongxiu Guo

School of Materials Science and Engineering, Northeastern University

Meishuan Li

Shenyang National Laboratory for Materials Sciences Chinese Academy of Sciences

Yang Yang

Shenyang National Laboratory for Materials Sciences Chinese Academy of Sciences

Linshan Wang

College of Science, Northeastern University

\section{Yuhai Qian}

Shenyang National Laboratory for Materials Sciences Chinese Academy of Sciences

Jun Zuo

Shenyang National Laboratory for Materials Sciences Chinese Academy of Sciences

Jingjun Xu

Shenyang National Laboratory for Materials Sciences Chinese Academy of Sciences

Changsheng Liu

School of Materials Science and Engineering, Northeastern University

\section{Research Article}

Keywords: Ti3SiC2; short-carbon-fibers; spark-plasma-sintering; microstructure; mechanical properties

Posted Date: April 1st, 2020

DOI: https://doi.org/10.21203/rs.3.rs-20282/v1

License: (c) (i) This work is licensed under a Creative Commons Attribution 4.0 International License.

Read Full License 


\title{
Investigation on microstructure and mechanical properties of short-carbon-fiber/ $\mathrm{Ti}_{3} \mathrm{SiC}_{2}$ composites
}

Guangqi He ${ }^{1,2}$, Rongxiu Guo ${ }^{1}$, Meishuan $\mathrm{Li}^{2}$, Yang Yang ${ }^{2,4}$, Linshan Wang ${ }^{3}$, Yuhai Qian ${ }^{2}$, Jun $\mathrm{Zuo}^{2}$, Jingjun $\mathrm{Xu}^{2, *}$, Changsheng Liu ${ }^{1, *}$

${ }^{1}$ School of Materials Science and Engineering, Northeastern University, Shenyang 110819, China

${ }^{2}$ Shenyang National Laboratory for Materials Science, Institute of Metal Research, Chinese Academy of Sciences, Shenyang 110016, China

${ }^{3}$ College of Science, Northeastern University, Shenyang 110819, China

${ }^{4}$ School of Materials Science and Engineering, University of Science and Technology of China, Shenyang 110016, China

\begin{abstract}
In this paper, short-carbon-fibers $\left(\mathrm{C}_{\mathrm{sf}}\right)$ reinforced $\mathrm{Ti}_{3} \mathrm{SiC}_{2}$ matrix composites $\left(\mathrm{C}_{\text {sf }} / \mathrm{Ti}_{3} \mathrm{SiC}_{2}\right.$, the $\mathrm{C}_{\text {sf }}$ content was $0,2,5$ and 10 vol.\%) were fabricated by spark-plasmasintering (SPS) using $\mathrm{Ti}_{3} \mathrm{SiC}_{2}$ powders and $\mathrm{C}_{\mathrm{sf}}$ as starting materials at $1300{ }^{\circ} \mathrm{C}$. The effects of $\mathrm{C}_{\mathrm{sf}}$ addition on the phase compositions, microstructures and mechanical properties (including hardness, flexural strength and fracture toughness) of $\mathrm{C}_{\mathrm{s}} \mathrm{f} / \mathrm{Ti}_{3} \mathrm{SiC}_{2}$ composites

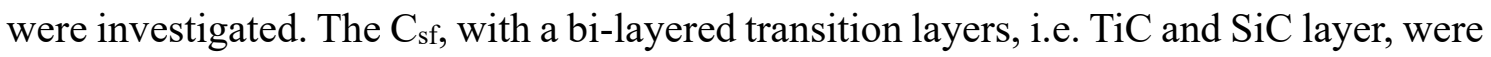
homogeneously distributed in the as-prepared $\mathrm{C}_{\mathrm{sf}} / \mathrm{Ti}_{3} \mathrm{SiC}_{2}$ composites. With the increase of $\mathrm{C}_{\mathrm{sf}}$ content, the fracture toughness of $\mathrm{C}_{\mathrm{sf}} / \mathrm{Ti}_{3} \mathrm{SiC}_{2}$ composites increased, but the flexural
\end{abstract}


strength decreased, while the Vickers hardness decreased initially then increased steadily when the $\mathrm{C}_{\text {sf }}$ content was higher than 2 vol.\%. These changed performances could be attributed to the introduction of $\mathrm{C}_{\mathrm{sf}}$ and the formation of much stronger interfacial phases.

Keywords: $\mathrm{Ti}_{3} \mathrm{SiC}_{2} ; \quad$ short-carbon-fibers; spark-plasma-sintering; microstructure; mechanical properties

* Corresponding authors.

E-mail addresses: jjxu@imr.ac.cn (Jingjun Xu); csliu@mail.neu.edu.cn (Changsheng Liu)

\section{Introduction}

$\mathrm{Ti}_{3} \mathrm{SiC}_{2}$, a typical member of the MAX phase family, is a ternary layered compound. It has attracted extensive attention for its unique combination of metals and ceramics properties, such as low density, easy machinability, high melting point, high tensile strength and damage tolerance, excellent thermal shock resistance, good chemical stability and oxidation resistance (below $900{ }^{\circ} \mathrm{C}$ ) [1-7]. Therefore, $\mathrm{Ti}_{3} \mathrm{SiC}_{2}$ is a potential structural material for the applications in the environments of high temperature, oxidation, corrosion and wear etc. $[1,2,7,8]$. However, low fracture toughness and hardness limit its practical applications. The introduction of secondary phase as reinforcement into $\mathrm{Ti}_{3} \mathrm{SiC}_{2}$ has been proved to be an effective approach to overcome these disadvantages. 
For example, numerous reinforcements, including $\mathrm{TiB}_{2}$ [9], $\mathrm{SiC}$ [10], c-BN [11], TiC [12], $\mathrm{Al}_{2} \mathrm{O}_{3}$ [13] and $\mathrm{ZrO}_{2}$ [14], have been introduced to improve the mechanical properties of $\mathrm{Ti}_{3} \mathrm{SiC}_{2}$. Commonly, the additions of ceramic particles can improve Vickers hardness and flexural strength of $\mathrm{Ti}_{3} \mathrm{SiC}_{2}$ matrix composites. For example, Górny et al. [9] reported that the addition of $\mathrm{TiB}_{2}$ could effectively improve the Vickers hardness and elastic modulus of $\mathrm{Ti}_{3} \mathrm{SiC}_{2}$. Tian et al. [12] prepared $\mathrm{Ti}_{3} \mathrm{SiC}_{2}-\mathrm{TiC}$ composites and found that the Vickers hardness of the composite increased with increasing TiC content up to 90 vol.\%, the flexural strength was enhanced by $64 \%$ when the content of TiC was 50 vol.\%. Wang et al. [13] fabricated $\mathrm{Ti}_{3} \mathrm{SiC}_{2}-\mathrm{xAl}_{2} \mathrm{O}_{3}(\mathrm{x}=0-20$ vol.\%) composites by spark-plasmasintering (SPS), found that $\mathrm{Ti}_{3} \mathrm{SiC}_{2}-20$ vol.\% $\mathrm{Al}_{2} \mathrm{O}_{3}$ exhibited the highest Vickers hardness, while other mechanical properties deteriorated because of the aggregation of $\mathrm{Al}_{2} \mathrm{O}_{3}$ in the composite. On the other hand, the toughness of $\mathrm{Ti}_{3} \mathrm{SiC}_{2}$ matrix composites has hardly ever been strengthened due to intrinsic brittleness of these ceramic phases.

Carbon fibers, with numerous attractively comprehensive properties, such as low density, high strength and modulus, excellent chemical inertness and small thermal expansion coefficient, are considered to be the most promising reinforcing phase for many structural ceramics [15-17]. Especially, Short-carbon-fibers $\left(\mathrm{C}_{\mathrm{sf}}\right)$ have been applied extensively in the preparation of ceramic matrix composites by using SPS or hot-pressing (HP), due to their low cost, easy to add, and chemical inert at high temperatures. Interestingly, $\mathrm{C}_{\mathrm{sf}}$ reinforced ceramic matrix composites usually possess relatively higher fracture toughness. For example, Wang et. al. [18] fabricated $\mathrm{C}_{\text {sf }}$ (up to $1 \mathrm{wt} . \%$ ) reinforced 
$\mathrm{B}_{4} \mathrm{C}$ composites, and found that the composites had higher fracture toughness compared with monolithic $\mathrm{B}_{4} \mathrm{C}$ due to the occurrence of crack deflection and bridging resulting from interface debonding between fiber and matrix. Similarly, when $\mathrm{C}_{\text {sf }}$ was introduced in $\mathrm{ZrB}_{2}-\mathrm{SiC}$ composites, the toughness of the composites was significantly improved, resulted from fiber debonding, pulling-out and bridging as well as crack deflection [19]. Unfortunately, to date, only Lagos et. al. prepared $\mathrm{Ti}_{3} \mathrm{SiC}_{2}-\mathrm{C}_{\mathrm{f}}$ composites by SPS, and processing, microstructure and thermo-mechanical properties (thermal expansion coefficient and thermal conductivity) were investigated [20], while the mechanical properties of $\mathrm{C}_{\mathrm{sf}}$ reinforced $\mathrm{Ti}_{3} \mathrm{SiC}_{2}$ composites are not available.

In this work, $\mathrm{C}_{\mathrm{sf}} / \mathrm{Ti}_{3} \mathrm{SiC}_{2}$ composites (the content of $\mathrm{C}_{\mathrm{sf}}$ was $0,2,5$ and 10 vol.\%) were fabricated by using SPS technique. The interfacial microstructure between $\mathrm{C}_{\text {sf }}$ and $\mathrm{Ti}_{3} \mathrm{SiC}_{2}$ matrix and effects of $\mathrm{C}_{\mathrm{sf}}$ introduction on room-temperature mechanical properties of $\mathrm{C}_{\mathrm{s}} / \mathrm{Ti}_{3} \mathrm{SiC}_{2}$ composites were systematically investigated, and the role of $\mathrm{C}_{\text {sf }}$ addition played in reinforcement effect was also discussed.

\section{Experimental}

\subsection{Materials preparation}

$\mathrm{Ti}_{3} \mathrm{SiC}_{2}$ powders (Forsman Technology Co., Beijing, China) and $\mathrm{C}_{\mathrm{sf}}$ (ZLXC, Co.,

Cangzhou, China) were used as raw materials. The purity and mean particle size of $\mathrm{Ti}_{3} \mathrm{SiC}_{2}$ powders was $98 \%$ and $3 \sim 5 \mu \mathrm{m}$, respectively, and the main impurity was $\mathrm{Al}_{2} \mathrm{O}_{3}$. The length and diameter of $\mathrm{C}_{\mathrm{sf}}$ was $3 \mathrm{~mm}$ and $7 \mu \mathrm{m}$, respectively. Four $\mathrm{C}_{\mathrm{sf}} / \mathrm{Ti}_{3} \mathrm{SiC}_{2}$ 
composites with $\mathrm{C}_{\text {sf }}$ volume fractions of $0,2,5,10 \%$ were fabricated by using SPS (SPS30T-15-3, Chenhua (Shanghai) Technology Co., Ltd, Shanghai, China). For convenience, the composites were denoted as 2,5 and $10 \mathrm{C}_{\mathrm{sf}} / \mathrm{Ti}_{3} \mathrm{SiC}_{2}$, accordingly.

The preparation process of $\mathrm{C}_{\mathrm{sf}} / \mathrm{Ti}_{3} \mathrm{SiC}_{2}$ composites is schematically illustrated in Fig. 1. Firstly, $\mathrm{C}_{\mathrm{sf}}$ was dispersed into deionized water with carboxymethyl cellulose sodium (CMC-Na) as the dispersant. The mass ratio of CMC-Na and $\mathrm{C}_{\text {sf }}$ was 1:3. Then, $\mathrm{Ti}_{3} \mathrm{SiC}_{2}$ powders were added into the as-prepared solution. After stirring with a magnetic stirrer, the slurry of $\mathrm{Ti}_{3} \mathrm{SiC}_{2}$ powders and $\mathrm{C}_{\mathrm{sf}}$ was obtained. Dried in an oven, the mixed material was packed into a cylindrical graphite die. Followed that, a green body with a diameter of $\Phi 40 \mathrm{~mm}$ was obtained by cold pressing under a load of $20 \mathrm{MPa}$. Subsequently, the sintering was conducted in SPS facility. After the vacuum of $10 \mathrm{~Pa}$ in the sintering chamber was acquired, the green body was heated to $1300{ }^{\circ} \mathrm{C}$, under a constant pressure of $40 \mathrm{MPa}$ soaked for $8 \mathrm{~min}$, then cooled to room temperature in the sintering chamber. All composites were fabricated under such identical SPS condition.

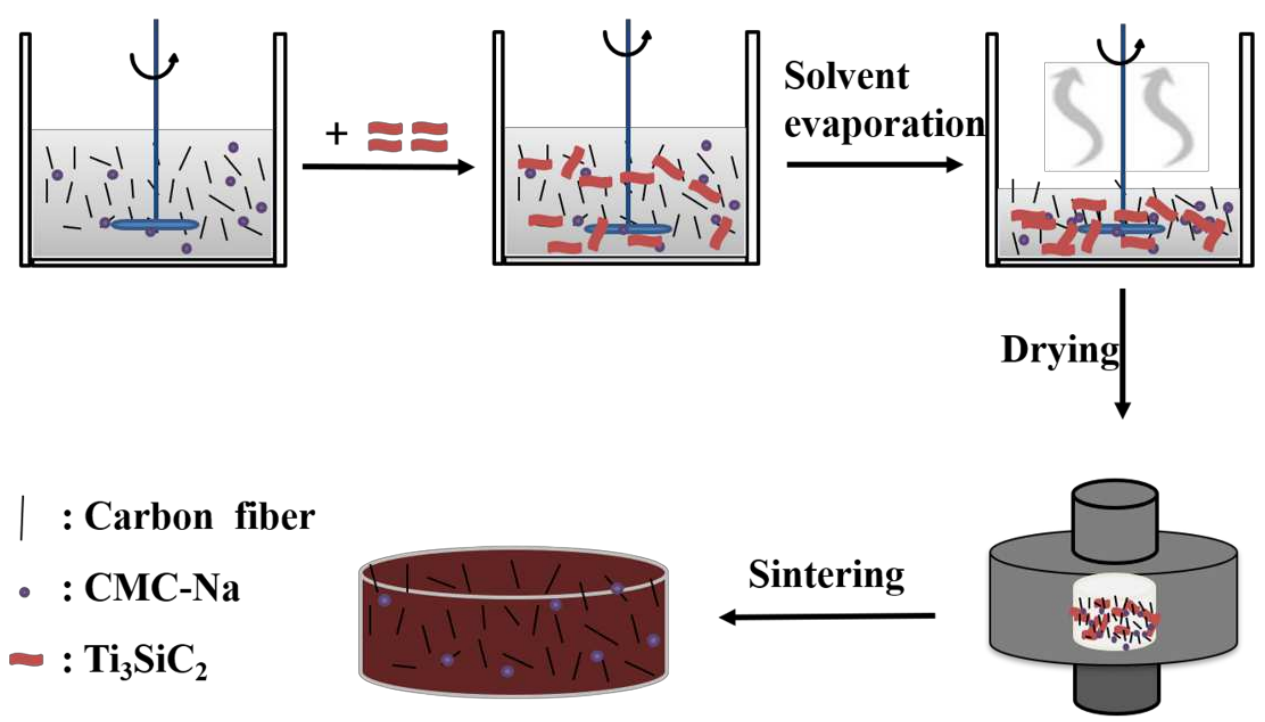


Fig. 1 Schematic illustrations of the preparation process of $\mathrm{C}_{\mathrm{sf}} / \mathrm{Ti}_{3} \mathrm{SiC}_{2}$ composites by using SPS.

\subsection{Characterizations of composition and microstructure of the composites}

Determinations of actual densities of $\mathrm{C}_{\mathrm{sf}} / \mathrm{Ti}_{3} \mathrm{SiC}_{2}$ composites by Archimedes' method. X-ray diffraction (XRD, Rigaku, Japan) with $\mathrm{Cu} \mathrm{K \alpha}$ radiation was used to identified phase compositions of the samples. The microstructure, cross-section morphologies and fracture surfaces of the composites were performed by scanning electron microscope (SEM, Oberkochen, Germany) with energy dispersive spectrometer (EDS, Oxford Instruments, UK).

\subsection{Determinations of mechanical properties}

For mechanical tests, the samples were cut into a series of bars from the as-prepared composites by electrical discharge machining. Before testing, the surfaces of all samples were sanded to $2000^{\#} \mathrm{SiC}$ sandpaper, polished to a mirror surface with $1.0 \mathrm{~mm}$ diamond paste, then ultrasonically cleaned in ethanol and distilled water, finally dried.

Vickers hardness test was carried out using Vickers indenter (432SVD, WOLPERT, USA) at a load of $9.8 \mathrm{~N}$ for $15 \mathrm{~s}$. The parallel operations were conducted for nine times, finally the mean value was obtained for each sample.

Three-point bending tests were employed to determine flexural strength. The dimensions of rectangular samples were $3 \mathrm{~mm} \times 4 \mathrm{~mm} \times 34 \mathrm{~mm}$. During tests, the 
crosshead speed and support span were $0.5 \mathrm{~mm} / \mathrm{min}$ and $30 \mathrm{~mm}$, respectively. The flexural strength $\left(\sigma_{f}\right)$ was calculated by the following Eq. (1):

$$
\sigma_{\mathrm{f}}=\frac{3 \mathrm{~F}(\mathrm{~N}) \mathrm{L}}{2 \mathrm{BW}}
$$

Where, $\mathrm{F}(\mathrm{N})$ is maximum load, $\mathrm{L}$ is support span, B and $\mathrm{W}$ are width and height of the rectangular sample, respectively.

Four-point bending tests were employed to determine fracture toughness. The dimensions of rectangular samples were $4 \mathrm{~mm} \times 8 \mathrm{~mm} \times 34 \mathrm{~mm}$. The tested bars were machined as the single-edge-notched-beam (SENB) with the depth of $4 \mathrm{~mm}$ and the width of $0.2 \mathrm{~mm}$. During tests, the crosshead speed was $0.05 \mathrm{~mm} / \mathrm{min}$, and the inner span and outer span were $10 \mathrm{~mm}$ and $30 \mathrm{~mm}$, respectively. The fracture toughness $\left(K_{\mathrm{IC}}\right)$ was calculated by the following Eqs. (2) and (3)

$$
\begin{gathered}
K_{\mathrm{IC}}=\frac{\mathrm{F}(\mathrm{N})}{\mathrm{B}} \frac{\mathrm{s}}{\mathrm{W}^{3 / 2}} \mathrm{f}\left(\frac{\mathrm{C}}{\mathrm{W}}\right) \\
\mathrm{f}\left(\frac{\mathrm{C}}{\mathrm{W}}\right)=2.9\left(\frac{\mathrm{C}}{\mathrm{W}}\right)^{1 / 2}-4.6\left(\frac{\mathrm{C}}{\mathrm{W}}\right)^{3 / 2}+21.8\left(\frac{\mathrm{C}}{\mathrm{W}}\right)^{5 / 2}-37.6\left(\frac{\mathrm{C}}{\mathrm{W}}\right)^{3 / 2}+38.7\left(\frac{\mathrm{C}}{\mathrm{W}}\right)^{9 / 2}
\end{gathered}
$$

Where, $\mathrm{C}$ is notch length, $\mathrm{B}$ and $\mathrm{W}$ are the width and height of the sample, respectively.

\section{Results and discussion}

\subsection{Phase compositions of the composites}

Fig. 2 shows XRD patterns of $\mathrm{C}_{\mathrm{sf}} / \mathrm{Ti}_{3} \mathrm{SiC}_{2}$ composites with various volume amounts of $\mathrm{C}_{\text {sf. }}$ For $\mathrm{Ti}_{3} \mathrm{SiC}_{2}$ and $2 \mathrm{C}_{\mathrm{sf}} / \mathrm{Ti}_{3} \mathrm{SiC}_{2}$, main phase was identified as $\mathrm{Ti}_{3} \mathrm{SiC}_{2}$, and a small amount of $\mathrm{Al}_{2} \mathrm{O}_{3}$ impurity could be detected as well. However, when the content of $\mathrm{C}_{\text {sf }}$ was increased to 5 and 10 vol.\%, two impurities of TiC and SiC appeared. And, the peak 
intensities of $\mathrm{TiC}$ and $\mathrm{SiC}$ increased simultaneously with an increase of $\mathrm{C}_{\text {sf }}$ content in $\mathrm{C}_{\mathrm{sf}} / \mathrm{Ti}_{3} \mathrm{SiC}_{2}$ composites. In all three composites, $\mathrm{C}_{\mathrm{sf}}$ was not identified, which may result from the low weight content of $\mathrm{C}_{\mathrm{sf}}$ in the composites. The formation of $\mathrm{TiC}$ and $\mathrm{SiC}$ were caused mainly by the interface reaction between $\mathrm{C}_{\text {sf }}$ and $\mathrm{Ti}_{3} \mathrm{SiC}_{2}$ [21], which will be discussed in the following section.

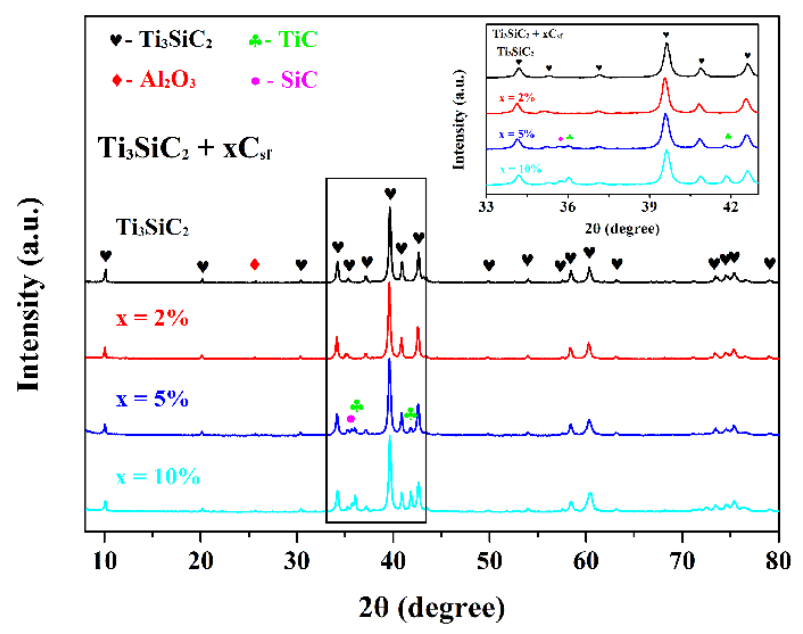

Fig. 2 XRD patterns of $\mathrm{C}_{\mathrm{sf}} / \mathrm{Ti}_{3} \mathrm{SiC}_{2}$ composites with the different contents of $\mathrm{C}_{\text {sf. }}$ The inset shows the enlarged views in the $2 \theta$ range of $33^{\circ}-43^{\circ}$.

\subsection{Microstructures of the composites}

SEM micrographs of the polished surfaces of the as-prepared $\mathrm{Ti}_{3} \mathrm{SiC}_{2}$ and $\mathrm{C}_{\mathrm{sf}} / \mathrm{Ti}_{3} \mathrm{SiC}_{2}$ composites are presented in Fig. 3. Minor micro-pores existed in the $\mathrm{Ti}_{3} \mathrm{SiC}_{2}$ sample (Fig. 3(a)). For the $\mathrm{C}_{\mathrm{sf}} / \mathrm{Ti}_{3} \mathrm{SiC}_{2}$ composites (Fig. 3(b, c, d)), the black circle-like and stripe-like $\mathrm{C}_{\mathrm{sf}}$ were uniformly dispersed in the gray $\mathrm{Ti}_{3} \mathrm{SiC}_{2}$ matrix, and exhibited various orientations in a three-dimensional space. Additionally, the average length (100 $\mu \mathrm{m})$ of $\mathrm{C}_{\mathrm{sf}}$ in the $\mathrm{Ti}_{3} \mathrm{SiC}_{2}$ matrix was apparently shorter than their original length (3-5 
$\mathrm{mm}$ ). The reduction in $\mathrm{C}_{\mathrm{sf}}$ length is caused by the applied pressure during sintering process.[22] And, no pores were found in these composites, indicating that the well dispersed $\mathrm{C}_{\text {sf }}$ could promote the densification of $\mathrm{Ti}_{3} \mathrm{SiC}_{2}$ matrix. The most conceivable reason is that the incorporation of $\mathrm{C}_{\mathrm{sf}}$ resulted in the existence of more phase boundaries, which is beneficial to the elimination of pores. The fact that $\mathrm{C}_{\mathrm{sf}}$ well dispersed in the $\mathrm{Ti}_{3} \mathrm{SiC}_{2}$ matrix confirmed the suitable fabrication approach of these composites at present.
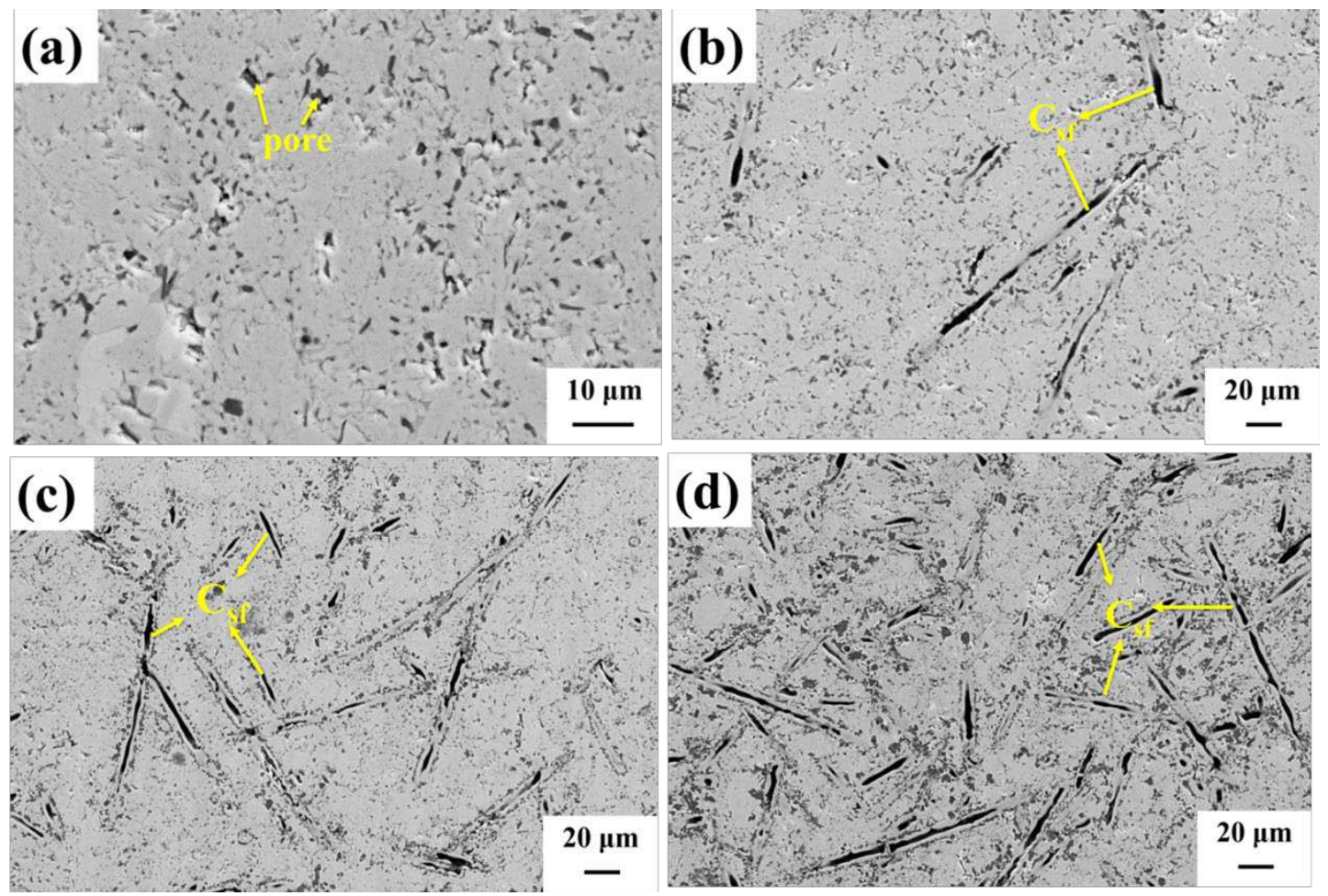

Fig. 3 SEM micrographs of the polished surfaces of (a) $\mathrm{Ti}_{3} \mathrm{SiC}_{2}$, (b) $2 \mathrm{C}_{\mathrm{sf}} / \mathrm{Ti}_{3} \mathrm{SiC}_{2}$, (c) 5 $\mathrm{C}_{\mathrm{sf}} / \mathrm{Ti}_{3} \mathrm{SiC}_{2}$ and (d) $10 \mathrm{C}_{\mathrm{sf}} / \mathrm{Ti}_{3} \mathrm{SiC}_{2}$.

To understand the bonding of $\mathrm{C}_{\mathrm{sf}}$ and $\mathrm{Ti}_{3} \mathrm{SiC}_{2}$ well, the polished cross-section morphology of $10 \mathrm{C}_{\mathrm{s}} / \mathrm{Ti}_{3} \mathrm{SiC}_{2}$ was observed by SEM, and elemental distribution was identified by EDS, the results are presented in Fig. 4. According to Fig. 4 (a) and (b), there were two carbon fibers, which orientation was perpendicular to the viewing plane. The 
bonding of $\mathrm{C}_{\mathrm{sf}}$ and $\mathrm{Ti}_{3} \mathrm{SiC}_{2}$ matrix was very strong, no any pores or flaws could be observed in the interface zone. The chemical compositions of the selected zones 1-5 in Fig. 4 (b) were determined by EDS, as listed in Table 1. It was found that the interface phase with duplex structure was formed between $\mathrm{C}_{\text {sf }}$ and $\mathrm{Ti}_{3} \mathrm{SiC}_{2}$ matrix. Based on EDS analysis results, the inner interface layer adjacent to $\mathrm{C}_{\text {sf }}$ was identified as $\mathrm{TiC}$, while the outer interface layer was $\mathrm{SiC}$. Such result was quite different from the results of $\mathrm{Ti}_{3} \mathrm{SiC}_{2}-$ $\mathrm{C}_{\mathrm{f}}$ composites prepared by Lagos et al [20]. The main reason is that our experiments actively increased the dwell time from $5 \mathrm{~min}$ to $8 \mathrm{~min}$ to improve the relative densities of $\mathrm{C}_{\mathrm{sf}} / \mathrm{Ti}_{3} \mathrm{SiC}_{2}$ composites, which is favorable to the occurrence of the reaction between $\mathrm{C}_{\mathrm{sf}}$ and $\mathrm{Ti}_{3} \mathrm{SiC}_{2}$.
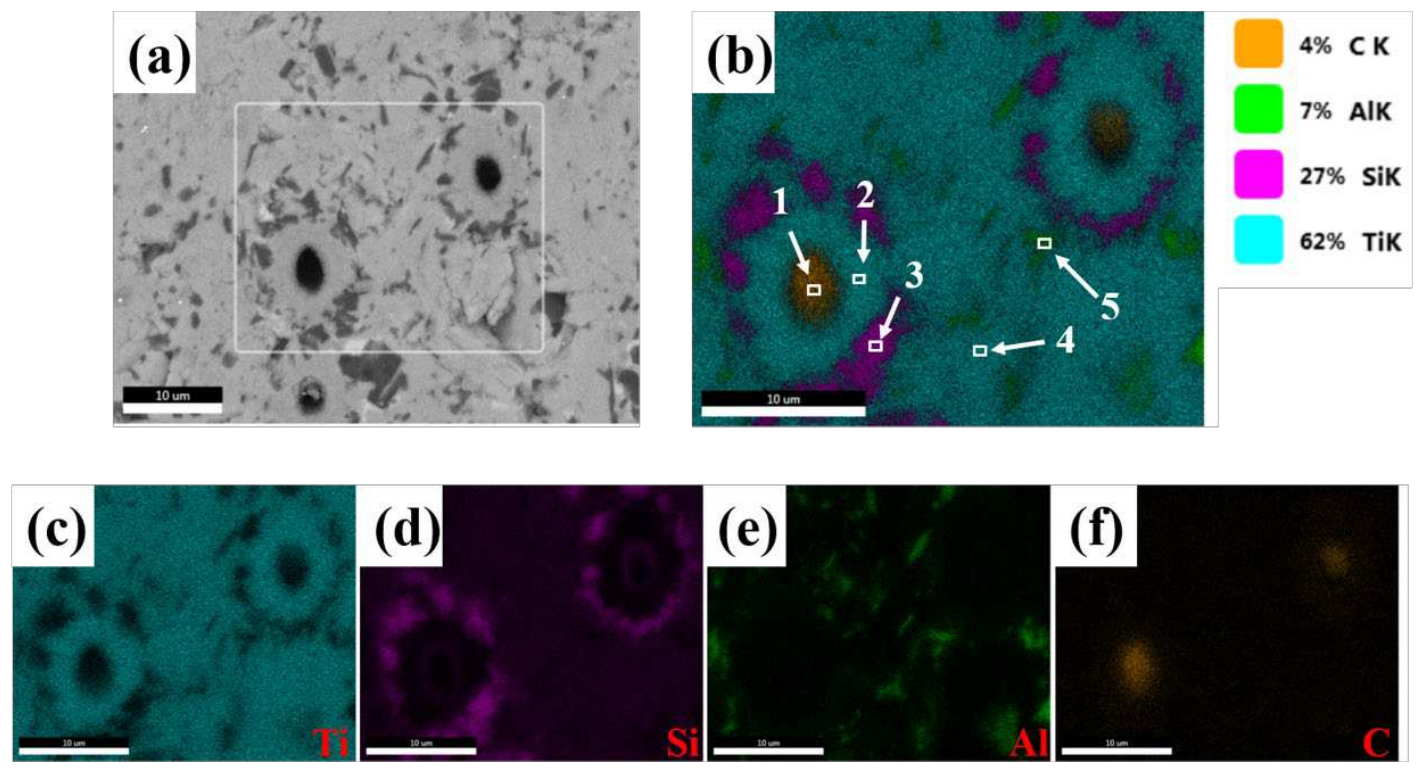

Fig. 4 (a) SEM image of polished cross section of $10 \mathrm{C}_{\mathrm{s}} / \mathrm{Ti}_{3} \mathrm{SiC}_{2}$; (b) element mappings in the white frame area in Fig. 4 (a); element distributions of (c) Ti, (d) Si, (e) Al, and (f) C. 
Table 1 EDS results of the marked spots 1-5 in Fig. 4(b).

\begin{tabular}{ccccccc}
\hline \multirow{2}{*}{$\begin{array}{c}\text { Marked } \\
\text { zone }\end{array}$} & $\mathrm{Ti}$ & $\mathrm{Si}$ & $\mathrm{Al}$ & $\mathrm{C}$ & $\mathrm{O}$ & \multirow{2}{*}{$\begin{array}{c}\text { Corresponding } \\
\text { phase }\end{array}$} \\
\cline { 2 - 5 } 1 & 6.81 & 2.36 & 0.40 & 90.42 & - & $\mathrm{C}_{\text {sf }}$ \\
2 & 50.93 & 3.84 & 1.10 & 44.13 & - & $\mathrm{TiC}$ (rich in $\mathrm{Ti}$ ) \\
3 & 5.23 & 57.71 & 0.79 & 36.27 & - & $\mathrm{SiC}$ \\
4 & 45.56 & 15.34 & 0.59 & 38.51 & - & $\mathrm{Ti}_{3} \mathrm{SiC}_{2}$ \\
5 & 2.67 & 1.36 & 26.21 & 23.68 & 46.09 & $\mathrm{Al}_{2} \mathrm{O}_{3}$ \\
\hline
\end{tabular}

The interfacial reaction mechanism can be proposed tentatively based on the above SEM observations and EDS results. A literature reported show that $\mathrm{Ti}_{3} \mathrm{SiC}_{2}$ can maintain thermal stability at about $1300{ }^{\circ} \mathrm{C}$ [23]. Therefore, the above-mentioned phenomenon could be attributed to the environment-dependent decomposition behavior of $\mathrm{Ti}_{3} \mathrm{SiC}_{2}$, i.e., a carbon-rich environment will promote the decomposition of $\mathrm{Ti}_{3} \mathrm{SiC}_{2}$ and transform them into $\mathrm{TiC}_{0.67}$ and $\mathrm{Si}[23-25]$, as described by the reaction (4).

$$
\mathrm{Ti}_{3} \mathrm{SiC}_{2} \rightarrow 3 \mathrm{TiC}_{0.67}+\mathrm{Si}(\mathrm{g}) \quad(\Delta \mathrm{G}(1600 \mathrm{k})=181 \mathrm{~kJ} / \mathrm{mol})
$$

Furthermore, for the composites of $\mathrm{C}_{\mathrm{sf}} / \mathrm{Ti}_{3} \mathrm{SiC}_{2}$, due to the reaction of the added $\mathrm{C}_{\mathrm{sf}}$ could act as $\mathrm{C}$ reservoir and $\mathrm{Si}$ to form $\mathrm{SiC}$ (Eq. (5)) [23], the reaction (4) could be promoted by the consumption of Si.

$$
\mathrm{C}+\mathrm{Si}(\mathrm{g}) \rightarrow \mathrm{SiC}
$$

The formation of the $\mathrm{TiC}$ phase is due to the diffusion of $\mathrm{C}$ into the carbon vacancies in $\mathrm{TiC}_{0.67}$, as shown in the reaction (6).

$$
\mathrm{C}+\mathrm{TiC}_{0.67} \rightarrow \mathrm{TiC}
$$

As a result, a double-layered interface phases are formed, which can serve as a 
diffusion barrier and prevent $\mathrm{C}_{\mathrm{sf}}$ from providing a $\mathrm{C}$ source to inhibit the decomposition of $\mathrm{Ti}_{3} \mathrm{SC}_{2}$.

From the EDS result in Fig. 4(e), the bright agglomerates were enriched in Al. Meanwhile, the EDS analysis also confirmed the existence of minor well-dispersed $\mathrm{Al}_{2} \mathrm{O}_{3}$ particles with the size of 2-3 $\mu \mathrm{m}$, which corresponds to the XRD results.

The actual densities of the as-prepared composites are listed in Table 2. With increasing the content of $\mathrm{C}_{\mathrm{s}}$, the density of the composite decreased. This is because that the density of $\mathrm{C}_{\text {sf }}\left(1.78 \mathrm{~g} / \mathrm{cm}^{3}\right)$ was much lower than that of $\mathrm{Ti}_{3} \mathrm{SiC}_{2}\left(4.53 \mathrm{~g} / \mathrm{cm}^{3}\right)$. Based on the nominal ratio of the initial contents of $\mathrm{Ti}_{3} \mathrm{SiC}_{2}$ and $\mathrm{C}_{\mathrm{sf}}$, the theoretical densities of the as-prepared $\mathrm{Ti}_{3} \mathrm{SiC}_{2}$ and $\mathrm{C}_{\mathrm{s}} / \mathrm{Ti}_{3} \mathrm{SiC}_{2}$ composites were calculated using the rule of mixtures, also listed in Table 2. Obviously, the relative densities of all materials prepared by SPS were higher than $98 \%$ in this work. In addition, under the condition of the same SPS processing, the relative densities of the as-prepared $\mathrm{C}_{\mathrm{sf}} / \mathrm{Ti}_{3} \mathrm{SiC}_{2}$ composite increased with increasing $\mathrm{C}_{\text {sf }}$ content. It should be noted that, during the calculation of the theoretical densities of the composites, only the nominal composition of the composites were considered, the formation of high density TiC $\left(4.93 \mathrm{~g} / \mathrm{cm}^{3}[1]\right)$ during the sintering of the bulk material was neglected. Therefore, correspondingly, the higher contents of $\mathrm{C}_{\mathrm{sf}}$ as well as $\mathrm{TiC}$ led to the greater deviation of calculated density. 
Table 2 The determined and calculated densities of the as-prepared $\mathrm{Ti}_{3} \mathrm{SiC}_{2}$ and $\mathrm{C}_{\mathrm{s}} / \mathrm{Ti}_{3} \mathrm{SiC}_{2}$ composites.

\begin{tabular}{cccc}
\hline $\begin{array}{c}\text { Nominal } \\
\text { compositions (vol \%) }\end{array}$ & $\begin{array}{c}\text { Apparent density } \\
\left(\mathrm{g} \mathrm{cm}^{-3}\right)\end{array}$ & $\begin{array}{c}\text { Theoretical density } \\
\left(\mathrm{g} \mathrm{cm}^{-3}\right)\end{array}$ & $\begin{array}{c}\text { Relative } \\
\text { density (\%) }\end{array}$ \\
\hline $\mathrm{Ti}_{3} \mathrm{SiC}_{2}$ & 4.45 & 4.53 & 98.23 \\
$2 \mathrm{C}_{\mathrm{sf}} / \mathrm{Ti}_{3} \mathrm{SiC}_{2}$ & 4.41 & 4.47 & 98.65 \\
$5 \mathrm{C}_{\mathrm{s}} / \mathrm{Ti}_{3} \mathrm{SiC}_{2}$ & 4.35 & 4.39 & 99.09 \\
$10 \mathrm{C}_{\mathrm{sf}} / \mathrm{Ti}_{3} \mathrm{SiC}_{2}$ & 4.24 & 4.25 & 99.76 \\
\hline
\end{tabular}

\subsection{Mechanical properties of the composites}

\subsubsection{Vickers hardness}

The dependence of Vickers hardness of $\mathrm{Ti}_{3} \mathrm{SiC}_{2}$ and $\mathrm{C}_{\mathrm{s} f} / \mathrm{Ti}_{3} \mathrm{SiC}_{2}$ composites on the theoretical content of $\mathrm{C}_{\mathrm{sf}}$ is shown in Fig. 5. The Vickers hardness of the pristine $\mathrm{Ti}_{3} \mathrm{SiC}_{2}$ sintered by SPS in the present work was $5.40 \pm 0.06 \mathrm{GPa}$ (measured at the indentation load of $9.8 \mathrm{~N}$ ). It was reported previously that the hardness of monolithic $\mathrm{Ti}_{3} \mathrm{SiC}_{2}$ was about $4 \mathrm{GPa}$ [26], lower than that of $\mathrm{Ti}_{3} \mathrm{SiC}_{2}$ synthesized by SPS in this work. From Fig. 5, the Vickers hardness of the composite decreased slightly for the case of 2 vol. $\% \mathrm{C}_{\mathrm{sf}}$, and then increased monotonously to $6.80 \pm 0.87 \mathrm{GPa}$ with increasing $\mathrm{C}_{\text {sf }}$ content up to 10 vol.\%. For a small amount of $\mathrm{C}_{\mathrm{sf}}(2$ vol.\%) addition, the slightly decline of the hardness of the composite was related to $\mathrm{C}_{\text {sf }}$ possessing lower hardness compared to $\mathrm{Ti}_{3} \mathrm{SiC}_{2}$ matrix. The formation of minor $\mathrm{TiC}$ and $\mathrm{SiC}$ interfacial phases with the higher hardness of about 28-30 $\mathrm{GPa}$ [27] and $22 \mathrm{GPa}$ [28] compared to $\mathrm{Ti}_{3} \mathrm{SiC}_{2}$ matrix, respectively, was insufficient to compensate the hardness loss by the introduction of $\mathrm{C}_{\text {sf. }}$ For the 5 $\mathrm{C}_{\mathrm{sf}} / \mathrm{Ti}_{3} \mathrm{SiC}_{2}$, similar situation took place. Although the increased contents of $\mathrm{TiC}$ and $\mathrm{SiC}$ 
gave rise to the increased hardness of the composite, which was still lower than that of the matrix $\mathrm{Ti}_{3} \mathrm{SiC}_{2}$. When the content of $\mathrm{C}_{\mathrm{sf}}$ was $10 \mathrm{vol} . \%$, the hardness of the as-prepared composite was $6.80 \mathrm{GPa}$, which was larger than that of the $\mathrm{Ti}_{3} \mathrm{SiC}_{2}$. For the $10 \mathrm{C}_{\mathrm{sf}} / \mathrm{Ti}_{3} \mathrm{SiC}_{2}$, the contents of formed $\mathrm{TiC}$ and $\mathrm{SiC}$ interfacial phases with higher hardness was sufficient to compensate the hardness loss by the introduction of $\mathrm{C}_{\text {sf. }}$ Zhang et al. [29] presented that the maximum Vickers hardness of $\mathrm{Ti}_{3} \mathrm{SiC}_{2}-40$ vol.\% $\mathrm{TiC}$ composite was about 13 GPa. Accordingly, it is reasonable to believe that the contents of added $\mathrm{C}_{\text {sf }}$ and $\mathrm{TiC}$ derived from the interfacial reaction between $\mathrm{C}_{\mathrm{sf}}$ and $\mathrm{Ti}_{3} \mathrm{SiC}_{2}$ simultaneously determine the hardness of $\mathrm{C}_{\mathrm{sf}} / \mathrm{Ti}_{3} \mathrm{SiC}_{2}$ composite.

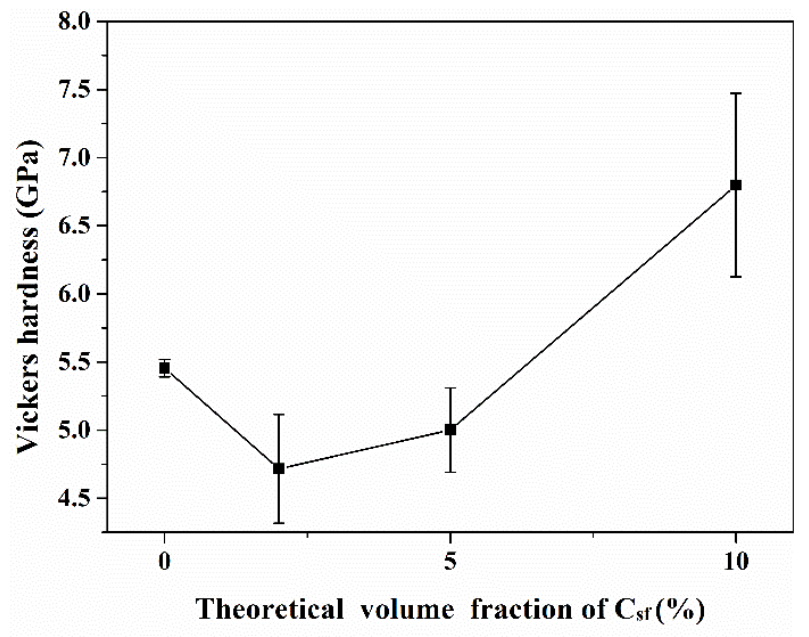

Fig. 5 The dependence of Vickers hardness of the as-prepared $\mathrm{C}_{\mathrm{sf}} / \mathrm{Ti}_{3} \mathrm{SiC}_{2}$ composites on the content of $\mathrm{C}_{\text {sf. }}$

\subsubsection{Flexural strength and fracture toughness}

The dependence of the flexural strength and fracture toughness of $\mathrm{Ti}_{3} \mathrm{SiC}_{2}$ and $\mathrm{C}_{\mathrm{sf}} / \mathrm{Ti}_{3} \mathrm{SiC}_{2}$ composites on the theoretical content of $\mathrm{C}_{\text {sf }}$ are illustrated in Fig. 6 . When the 
content of $\mathrm{C}_{\text {sf }}$ increased from 0 to 10 vol.\%, the flexural strength decreased from $602 \pm$ $34 \mathrm{MPa}$ to $468 \pm 34 \mathrm{MPa}$. The main reason for the deduction of flexural strength is that the modulus of $\mathrm{C}_{\mathrm{sf}}(\sim 250 \mathrm{GPa})$ is lower than that of $\mathrm{Ti}_{3} \mathrm{SiC}_{2}$ matrix $(\sim 326 \mathrm{GPa})$, and the presence of $\mathrm{C}_{\text {sf }}$ in the matrix resulted in the reduced load carrying capacity of the composites $[1,19]$. Meanwhile, it was also related to the formation of TiC with a high content between the matrix and $\mathrm{C}_{\mathrm{sf}}$, because the flexural strength of pure $\mathrm{TiC}$ is as low as 240-390 MPa [30].

It also can be clearly seen from Fig. 6 that as the increase of $\mathrm{C}_{\text {sf }}$ content, the fracture toughness of $\mathrm{C}_{\mathrm{s} f} / \mathrm{Ti}_{3} \mathrm{SiC}_{2}$ composites increased, reaching a maximum value of $6.48 \pm$ $0.29 \mathrm{MPa} \cdot \mathrm{m}^{1 / 2}$ for $10 \mathrm{C}_{\mathrm{s}} / \mathrm{Ti}_{3} \mathrm{SiC}_{2}$. After adding $\mathrm{C}_{\mathrm{sf}}$, the fracture toughness of $\mathrm{C}_{\mathrm{sf}} / \mathrm{Ti}_{3} \mathrm{SiC}_{2}$ composites were enhanced, which was related to the activation of certain kinds of toughening mechanisms [31, 32], as described as follows.

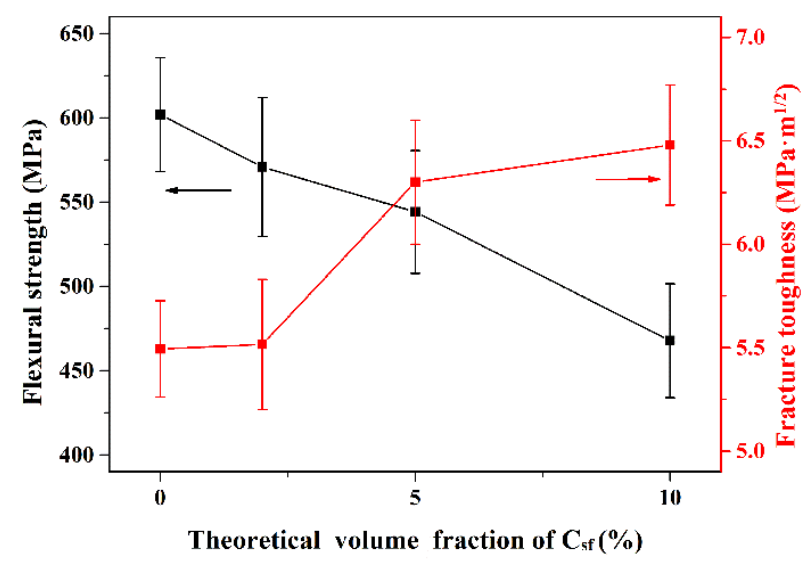

Fig. 6 The dependence of flexural strength and fracture toughness of the as-prepared $\mathrm{C}_{\mathrm{sf}} / \mathrm{Ti}_{3} \mathrm{SiC}_{2}$ composites on the content of $\mathrm{C}_{\text {sf. }}$.

The mechanical properties of fiber-reinforced composites rely on not only the intrinsic properties of fiber and matrix, but also the characteristics of fiber/matrix 
interface $[33,34]$. Interface delamination and the formation of a "weak" interphase are significantly vital to the comprehensive properties of fiber-reinforced ceramic matrix composites [35]. During the failure process of composites, their fracture toughness could be improved effectively by interface debonding, fiber bridging and fiber pulling-out caused by such characteristics mentioned above. To further understand the possible toughening mechanisms of the as-prepared $\mathrm{C}_{\mathrm{sf}}$ reinforced $\mathrm{Ti}_{3} \mathrm{SiC}_{2}$ composites, the fractured surfaces of the composites were observed by SEM after SENB test are shown in Fig. 7. Obviously, these composites exhibited a fully brittle fracture. The breakage of $\mathrm{C}_{\text {sf }}$ and interface debonding could be found, but fiber pull-out did not appear, corresponding to a strong interface bonding between $\mathrm{C}_{\mathrm{sf}}$ and $\mathrm{Ti}_{3} \mathrm{SiC}_{2}$. During the preparation of $\mathrm{C}_{\mathrm{sf}} / \mathrm{Ti}_{3} \mathrm{SiC}_{2}$ composites, original $\mathrm{C}_{\mathrm{sf}}$ did not undergo any surface treatment. As mentioned above, the formation of interfacial phases of $\mathrm{TiC}$ and $\mathrm{SiC}$ during heatpressing sintering caused an enhanced interface bonding between $\mathrm{C}_{\mathrm{sf}}$ and $\mathrm{Ti}_{3} \mathrm{SiC}_{2}$ matrix, and such chemical bonding was much stronger than van der Waals' force in the matrix $[36,37]$. Therefore, the fiber bridging or fiber pulling-out became very difficult to occur due to the presence of strong interface between fiber reinforcement and matrix $[34,38]$. On the other hand, under this condition, as the $\mathrm{C}_{\text {sf }}$ content increases, more energy is consumed during fracture process due to interface debonding and $\mathrm{C}_{\text {sf }}$ breakage, thereby resulting in the increased fracture toughness of the as-prepared composite. 

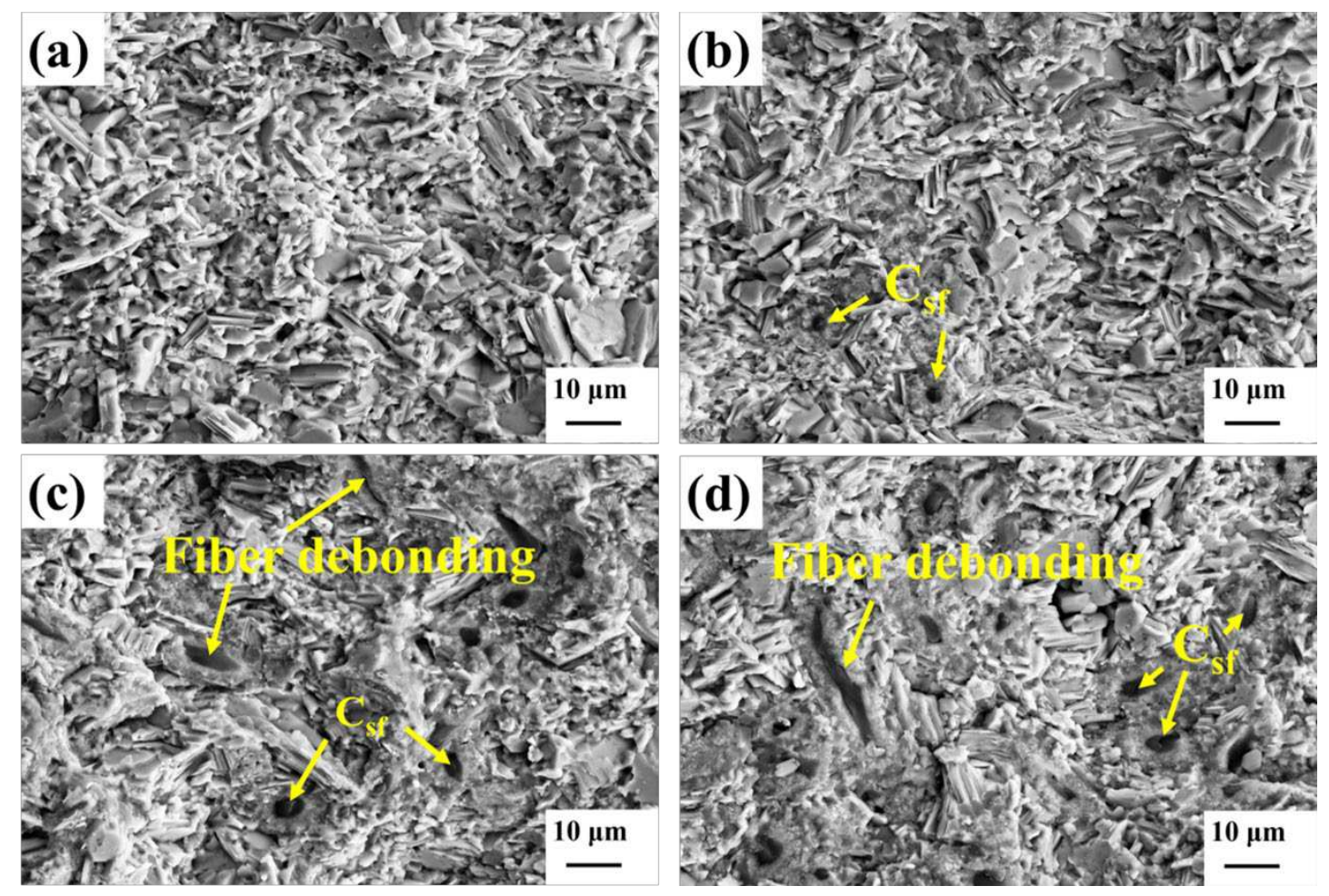

Fig. 7 SEM micrographs of the fracture surfaces of (a) $\mathrm{Ti}_{3} \mathrm{SiC}_{2}$, (b) $2 \mathrm{C}_{\mathrm{s} f} / \mathrm{Ti}_{3} \mathrm{SiC}_{2}$, (c) 5 $\mathrm{C}_{\mathrm{s}} / \mathrm{Ti}_{3} \mathrm{SiC}_{2}$ and (d) $10 \mathrm{C}_{\mathrm{sf}} / \mathrm{Ti}_{3} \mathrm{SiC}_{2}$.

\section{Conclusions}

$\mathrm{C}_{\text {sf }}$ reinforced $\mathrm{Ti}_{3} \mathrm{SiC}_{2}$ composites were prepared by SPS process. The behavior of $\mathrm{C}_{\mathrm{sf}}$ in the as-prepared $\mathrm{C}_{\mathrm{sf}} / \mathrm{Ti}_{3} \mathrm{SiC}_{2}$ composites, microstructures and mechanical properties of the as-prepared $\mathrm{C}_{\mathrm{sf}} / \mathrm{Ti}_{3} \mathrm{SiC}_{2}$ composites were studied. The main results are as follows:

(1) Dense $\mathrm{C}_{\mathrm{sf}} / \mathrm{Ti}_{3} \mathrm{SiC}_{2}$ composites with 2, 5, 10 vol.\% $\mathrm{C}_{\mathrm{sf}}$ were prepared by SPS at 1300 ${ }^{\circ} \mathrm{C}$. The interfacial reaction layer with duplex structure of $\mathrm{TiC}$ inner layer and $\mathrm{SiC}$ outer layer was formed between $\mathrm{C}_{\mathrm{sf}}$ and $\mathrm{Ti}_{3} \mathrm{SiC}_{2}$ matrix.

(2) Among the as-prepared $\mathrm{Ti}_{3} \mathrm{SiC}_{2}$ matrix composites, the one with 10 vol.\% $\mathrm{C}_{\mathrm{sf}}$ exhibited the highest Vickers hardness $(6.80 \pm 0.87 \mathrm{GPa})$ and fracture toughness 
$\left(6.48 \pm 0.29 \mathrm{MPa} \cdot \mathrm{m}^{1 / 2}\right)$, which were increased by $36.7 \%$ and $17.8 \%$ compared with $\mathrm{Ti}_{3} \mathrm{SiC}_{2}$, respectively. Its flexural strength was $467.7 \mathrm{MPa}$, decreased by $22.3 \%$.

(3) The contents of added $\mathrm{C}_{\mathrm{sf}}$ and $\mathrm{TiC}$ produced by the interfacial reaction between $\mathrm{C}_{\mathrm{sf}}$ and $\mathrm{Ti}_{3} \mathrm{SiC}_{2}$ matrix played a critical part in the mechanical properties of $\mathrm{C}_{\mathrm{s}} / \mathrm{Ti}_{3} \mathrm{SiC}_{2}$ composites.

\section{Acknowledgements}

This work was supported by the National Natural Science Foundation of China (Grant Nos. 51571203, 51571205) as well as Science and Technology Foundation of National Defense Key Laboratory (Grant No. HTKJ2019KL703006).

\section{References}

[1] Barsoum MW. The MN+1AXN phases: A new class of solids: Thermodynamically stable nanolaminates. Prog Solid State Chem 2000, 28: 201-281.

[2] Barsoum MW, El-Raghy T. Synthesis and characterization of a remarkable ceramic: Ti3 $\mathrm{SiC}_{2}$. J Am Ceram Soc 1996, 79: 1953-1956.

[3] El-Raghy T, Zavaliangos A, Barsoum MW, et al. Damage Mechanisms around Hardness Indentations in $\mathrm{Ti}_{3} \mathrm{SiC}_{2} . J$ Am Ceram Soc 2005, 80: 513-516.

[4] Barsoum M, El-Raghy T. A progress report on $\mathrm{Ti}_{3} \mathrm{SiC}_{2}, \mathrm{Ti}_{3} \mathrm{GeC}_{2}$, and the H-phases, M2BX. J Mater Synth Process 1997, 5: 197-216.

[5] Zhou Y, Sun Z, Chen S, et al. In-situ hot pressing/solid-liquid reaction synthesis of 
dense titanium silicon carbide bulk ceramics. Mater Res Innovations 1998, 2: 142146.

[6] Sun Z, Zhou Y, Li M. Oxidation behaviour of $\mathrm{Ti}_{3} \mathrm{SiC}_{2}$-based ceramic at $900-1300^{\circ} \mathrm{C}$ in air. Corros Sci 2001, 43: 1095-1109.

[7] Gao NF, Miyamoto Y, Zhang D. Dense Ti3 SiC$_{2}$ prepared by reactive HIP. J Mater Sci 1999, 34: 4385-4392.

[8] Ghosh NC, Harimkar SP. Phase analysis and wear behavior of in-situ spark plasma sintered $\mathrm{Ti}_{3} \mathrm{SiC}_{2}$. Ceram Int 2013, 39: 6777-6786.

[9] Górny G, Rączka M, Stobierski L, et al. Ceramic composite $\mathrm{Ti}_{3} \mathrm{SiC}_{2}-\mathrm{TiB}_{2}$ Microstructure and mechanical properties. Mater Charact 2009, 60: 1168-1174.

[10] Li S-B, Xie J-X, Zhang L-T, et al. Mechanical properties and oxidation resistance of $\mathrm{Ti}_{3} \mathrm{SiC}_{2} / \mathrm{SiC}$ composite synthesized by in situ displacement reaction of $\mathrm{Si}$ and $\mathrm{TiC}$. Mater Lett 2003, 57: 3048-3056.

[11] Benko E, Klimczyk P, Mackiewicz S, et al. cBN-Tii $\mathrm{SiC}_{2}$ composites. Diam Relat Mater 2004, 13: 521-525.

[12] Tian W, Sun Z, Hashimoto H, et al. Synthesis, microstructure and mechanical properties of $\mathrm{Ti}_{3} \mathrm{SiC}_{2}-\mathrm{TiC}$ composites pulse discharge sintered from $\mathrm{Ti} / \mathrm{Si} / \mathrm{TiC}$ powder mixture. Mater Sci Eng, A 2009, 526: 16-21.

[13] Wang HJ, Jin ZH, Miyamoto Y. Effect of $\mathrm{Al}_{2} \mathrm{O}_{3}$ on mechanical properties of $\mathrm{Ti}_{3} \mathrm{SiC}_{2} / \mathrm{Al}_{2} \mathrm{O}_{3}$ composite. Ceram Int 2002, 28: 931-934.

[14] Shi SL, Pan W. Toughening of $\mathrm{Ti}_{3} \mathrm{SiC}_{2}$ with 3 Y-TZP addition by spark plasma 
sintering. Mater Sci Eng, A 2007, 447: 303-306.

[15] Hou LG, Wu RZ, Wang XD, et al. Microstructure, mechanical properties and thermal conductivity of the short carbon fiber reinforced magnesium matrix composites. $J$ Alloys compd 2017, 695: 2820-2826.

[16] Li S, Zhang Y, Han J, et al. Effect of carbon particle and carbon fiber on the microstructure and mechanical properties of short fiber reinforced reaction bonded silicon carbide composite. J Eur Ceram Soc 2013, 33: 887-896.

[17] Hong W, Gui K, Hu P, et al. Preparation and characterization of high-performance $\mathrm{ZrB}_{2}-\mathrm{SiC}-\mathrm{C}_{\mathrm{f}}$ composites sintered at $1450{ }^{\circ} \mathrm{C} . \mathrm{J}$ Adv Ceram 2017, 6: 110-119.

[18] Wang M, Zhang Z, Sun Z, et al. Effect of fiber type on mechanical properties of short carbon fiber reinforced $\mathrm{B}_{4} \mathrm{C}$ composites. Ceram Int 2009, 35: 1461-1466.

[19] Yang F, Zhang X, Han J, et al. Characterization of hot-pressed short carbon fiber reinforced $\mathrm{ZrB}_{2}-\mathrm{SiC}$ ultra-high temperature ceramic composites. $J$ Alloys compd 2009, 472: 395-399.

[20] Lagos MA, Pellegrini C, Agote I, et al. $\mathrm{Ti}_{3} \mathrm{SiC}_{2}-\mathrm{Cf}$ composites by spark plasma sintering: Processing, microstructure and thermo-mechanical properties. J Eur Ceram Soc 2019, 39: 2824-2830.

[21] Li S-B, Xie J-X, Zhang L-T, et al. In situ synthesis of $\mathrm{Ti}_{3} \mathrm{SiC}_{2} / \mathrm{SiC}$ composite by displacement reaction of Si and TiC. Mater Sci Eng, A 2004, 381: 51-56.

[22] Gui K, Liu F, Wang G, et al. Microstructural evolution and performance of carbon fiber-toughened $\mathrm{ZrB}_{2}$ ceramics with $\mathrm{SiC}$ or $\mathrm{ZrSi} 2$ additive. J Adv Ceram 2018, 7: 
343-351.

[23] Racault C, Langlais F, Naslain R. Solid-state synthesis and characterization of the ternary phase $\mathrm{Ti}_{3} \mathrm{SiC}_{2}$. J Mater Sci 1994, 29: 3384-3392.

[24] El-Raghy T, Barsoum MW. Diffusion kinetics of the carburization and silicidation of $\mathrm{Ti}_{3} \mathrm{SiC}_{2}$. J Appl Phys 1998, 83: 112-119.

[25] Gao N, Miyamoto Y, Zhang D. On physical and thermochemical properties of highpurity $\mathrm{Ti}_{3} \mathrm{SiC}_{2}$. Mater Lett 2002, 55: 61-66.

[26] El-Raghy T, Blau P, Barsoum MW. Effect of grain size on friction and wear behavior of $\mathrm{Ti}_{3} \mathrm{SiC}_{2}$. Wear 2000, 238: 125-130.

[27] Ghosh NC, Harimkar SP. Microstructure and wear behavior of spark plasma sintered $\mathrm{Ti}_{3} \mathrm{SiC}_{2}$ and $\mathrm{Ti}_{3} \mathrm{SiC}_{2}$-TiC composites. Ceram Int 2013, 39: 4597-4607.

[28] Yin XW, Cheng LF, Zhang LT, et al. Fibre-reinforced multifunctional SiC matrix composite materials. Int Mater Rev 2016, 62: 117-172.

[29] Zhang J, Wang L, Jiang W, et al. Effect of TiC content on the microstructure and properties of $\mathrm{Ti}_{3} \mathrm{SiC}_{2}-\mathrm{TiC}$ composites in situ fabricated by spark plasma sintering. Mater Sci Eng, A 2008, 487: 137-143.

[30] Pierson HO. Processing of Refractory Carbides and Nitrides (Powder, Bulk, and Fibers)-14. Noyes Publications, New Jersey 1996: 248-275.

[31] Karimirad S, Balak Z. Characteristics of spark plasma sintered $\mathrm{ZrB}_{2}-\mathrm{SiC}-\mathrm{SCF}$ composites. Ceram Int 2019, 45: 6275-6281.

[32] Shahedi Asl M. Microstructure, hardness and fracture toughness of spark plasma 
sintered ZrB2-SiC-Cf composites. Ceram Int 2017, 43: 15047-15052.

[33] Brennan JJ, McCarthy G. Interfacial studies of refractory glass-ceramic matrix/advanced SiC-fiber reinforced composites. Mater Sci Eng, A 1993, 162: 5372.

[34] He X, Guo Y, Yu Z, et al. Study on microstructures and mechanical properties of short-carbon-fiber-reinforced $\mathrm{SiC}$ composites prepared by hot-pressing. Mater Sci Eng, $A$ 2009, 527: 334-338.

[35] Arai Y, Inoue R, Goto K, et al. Carbon fiber reinforced ultra-high temperature ceramic matrix composites: A review. Ceram Int 2019, 45: 14481-14489.

[36] Wang C, Chen L, Li J, et al. Enhancing the interfacial strength of carbon fiber reinforced epoxy composites by green grafting of poly (oxypropylene) diamines. Composites Part A 2017, 99: 58-64.

[37] Sun J, Zhao F, Yao Y, et al. High efficient and continuous surface modification of carbon fibers with improved tensile strength and interfacial adhesion. Appl Surf Sci 2017, 412: 424-435.

[38] Yang WS, Biamino S, Padovano E, et al. Microstructure and mechanical properties of short carbon fibre/SiC multilayer composites prepared by tape casting. Composites Sci Technol 2012, 72: 675-680. 


\section{Figure captions}

Fig. 1 Schematic illustrations of the preparation process of $\mathrm{C}_{\mathrm{s}} / \mathrm{Ti}_{3} \mathrm{SiC}_{2}$ composites by using SPS.

Fig. 2 XRD patterns of $\mathrm{C}_{\mathrm{s}} / \mathrm{Ti}_{3} \mathrm{SiC}_{2}$ composites with the different contents of $\mathrm{C}_{\text {sf. }}$. The inset shows the enlarged views in the $2 \theta$ range of $33^{\circ}-43^{\circ}$.

Fig. 3 SEM micrographs of the polished surfaces of (a) $\mathrm{Ti}_{3} \mathrm{SiC}_{2}$, (b) $2 \mathrm{C}_{\mathrm{sf}} / \mathrm{Ti}_{3} \mathrm{SiC}_{2}$, (c) 5 $\mathrm{C}_{\mathrm{sf}} / \mathrm{Ti}_{3} \mathrm{SiC}_{2}$ and (d) $10 \mathrm{C}_{\mathrm{sf}} / \mathrm{Ti}_{3} \mathrm{SiC}_{2}$.

Fig. 4 (a) SEM image of polished cross section of $10 \mathrm{C}_{\mathrm{s}} / \mathrm{Ti}_{3} \mathrm{SiC}_{2}$; (b) element mappings in the white frame area in Fig. 4 (a); element distributions of (c) Ti, (d) Si, (e) Al, and (f) C.

Fig. 5 The dependence of Vickers hardness of the as-prepared $\mathrm{C}_{\mathrm{s}} / \mathrm{Ti}_{3} \mathrm{SiC}_{2}$ composites on the content of $\mathrm{C}_{\text {sf. }}$

Fig. 6 The dependence of flexural strength and fracture toughness of the as-prepared $\mathrm{C}_{\mathrm{sf}} / \mathrm{Ti}_{3} \mathrm{SiC}_{2}$ composites on the content of $\mathrm{C}_{\text {sf. }}$.

Fig. 7 SEM micrographs of the fracture surfaces of (a) $\mathrm{Ti}_{3} \mathrm{SiC}_{2}$, (b) $2 \mathrm{C}_{\mathrm{sf}} / \mathrm{Ti}_{3} \mathrm{SiC}_{2}$, (c) 5 $\mathrm{C}_{\mathrm{sf}} / \mathrm{Ti}_{3} \mathrm{SiC}_{2}$ and (d) $10 \mathrm{C}_{\mathrm{sf}} / \mathrm{Ti}_{3} \mathrm{SiC}_{2}$. 
Figures
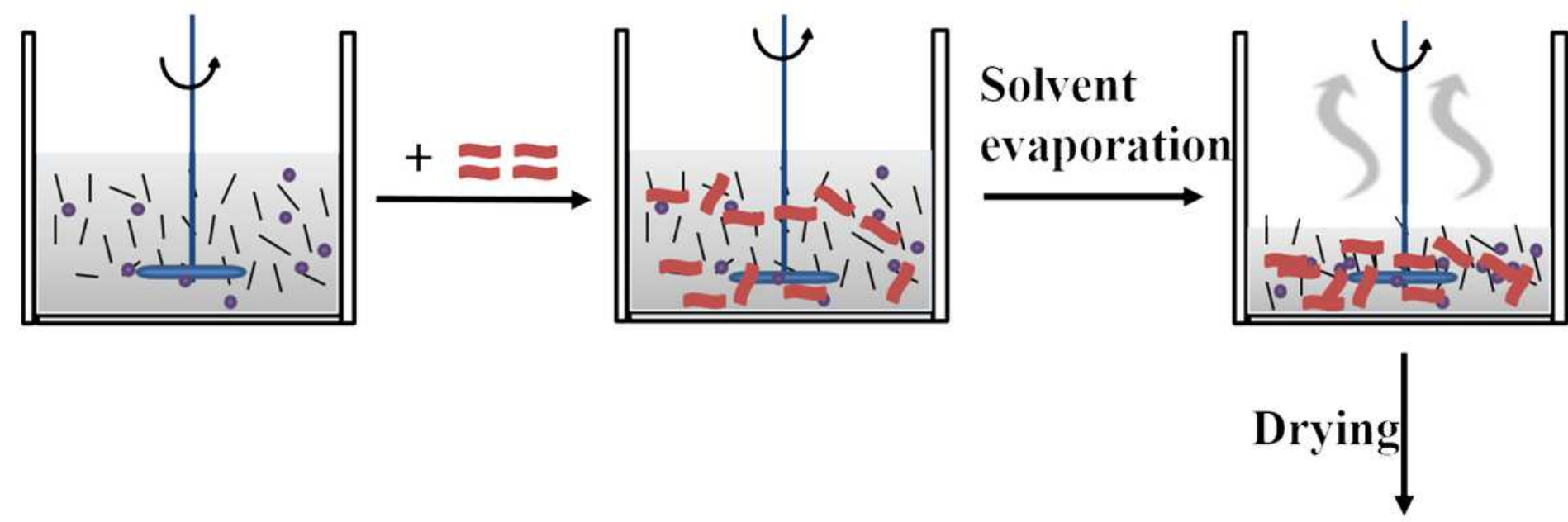

| : Carbon fiber

- : CMC-Na

$\sim: \mathrm{Ti}_{3} \mathrm{SiC}_{2}$

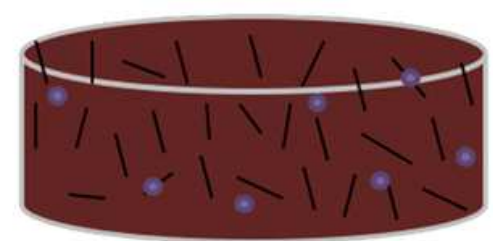

\section{Sintering}

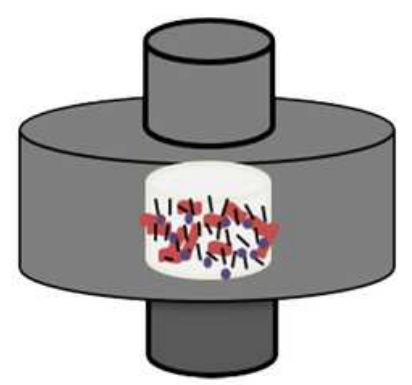

Figure 1

Schematic illustrations of the preparation process of Csf/Ti3SiC2 composites by using SPS. 


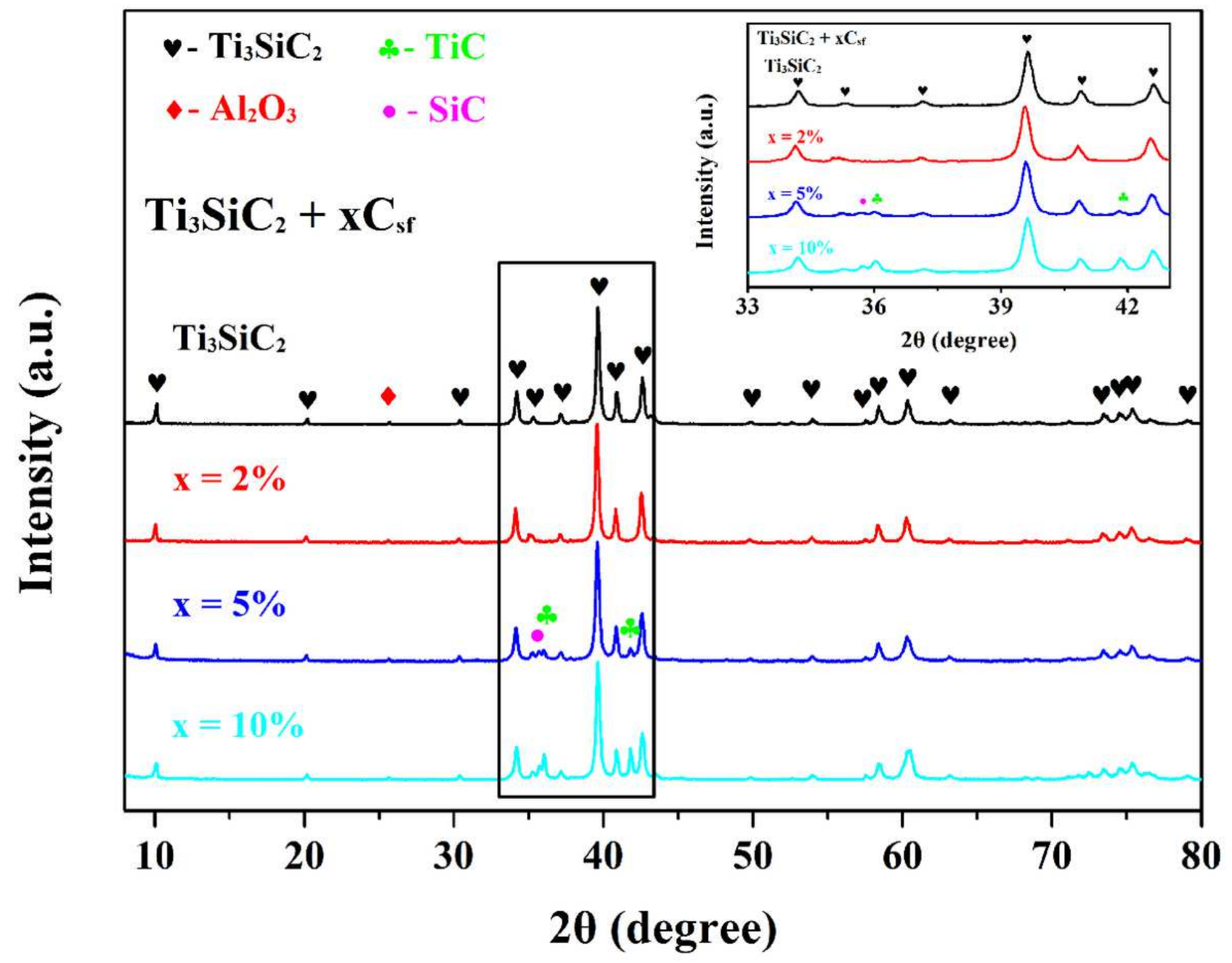

Figure 2

XRD patterns of Csf/Ti3SiC2 composites with the different contents of Csf. The inset shows the enlarged views in the $2 \theta$ range of $330-430$. 

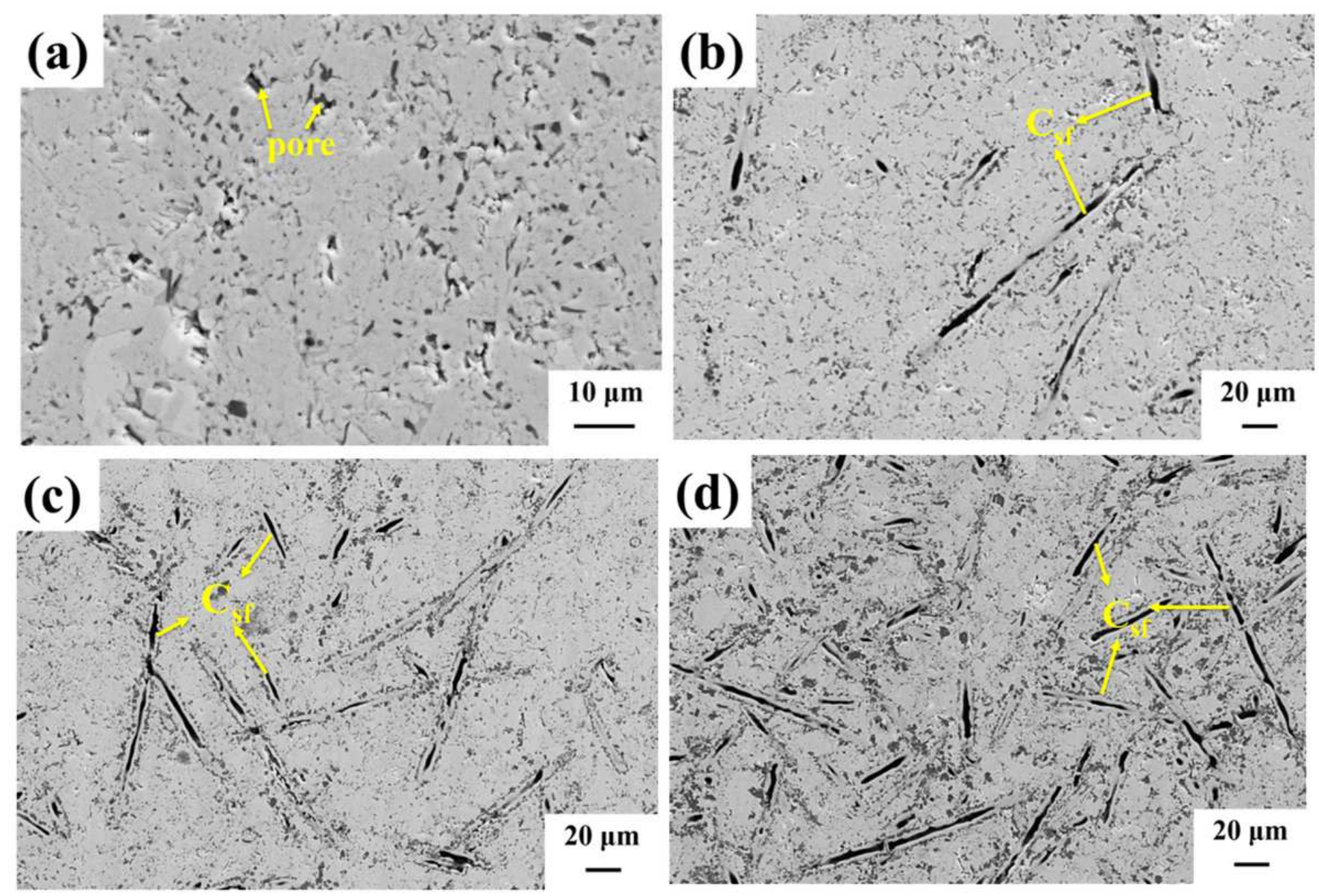

Figure 3

SEM micrographs of the polished surfaces of (a) Ti3SiC2, (b) 2 Csf/Ti3SiC2, (c) 5 Csf/Ti3SiC2 and (d) 10 Csf/Ti3SiC2. 

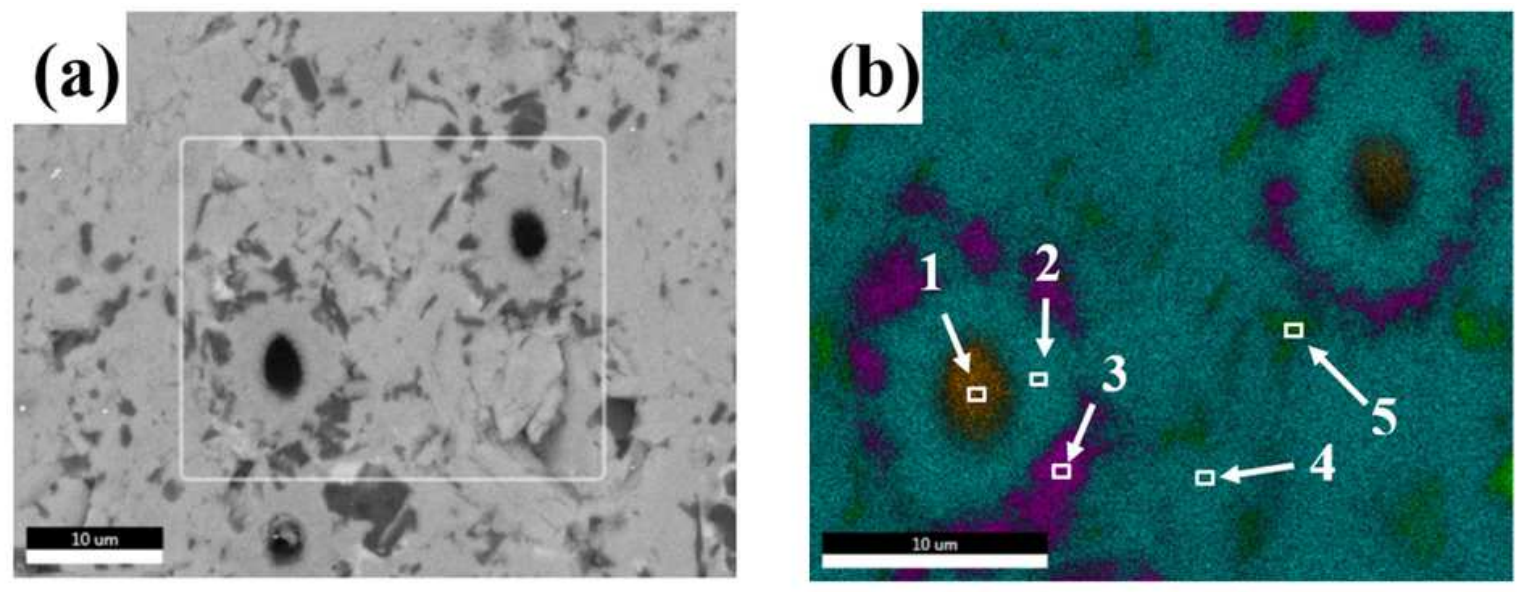

$4 \%$ C K

7\% AlK

$\mathbf{2 7} \%$ SiK $62 \%$ TiK
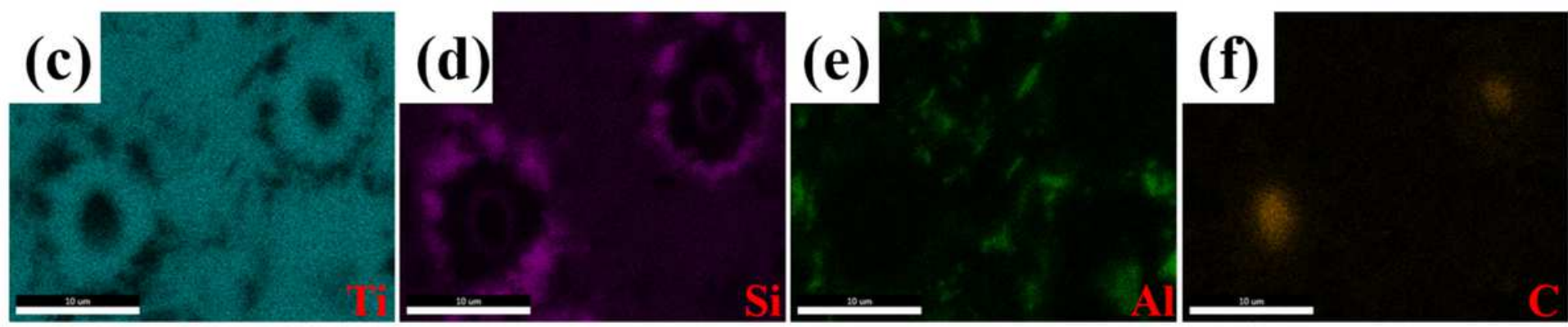

Figure 4

(a) SEM image of polished cross section of $10 \mathrm{Csf} / \mathrm{Ti3SiC2}$; (b) element mappings in the white frame area in Fig. 4 (a); element distributions of (c) Ti, (d) Si, (e) Al, and (f) C. 


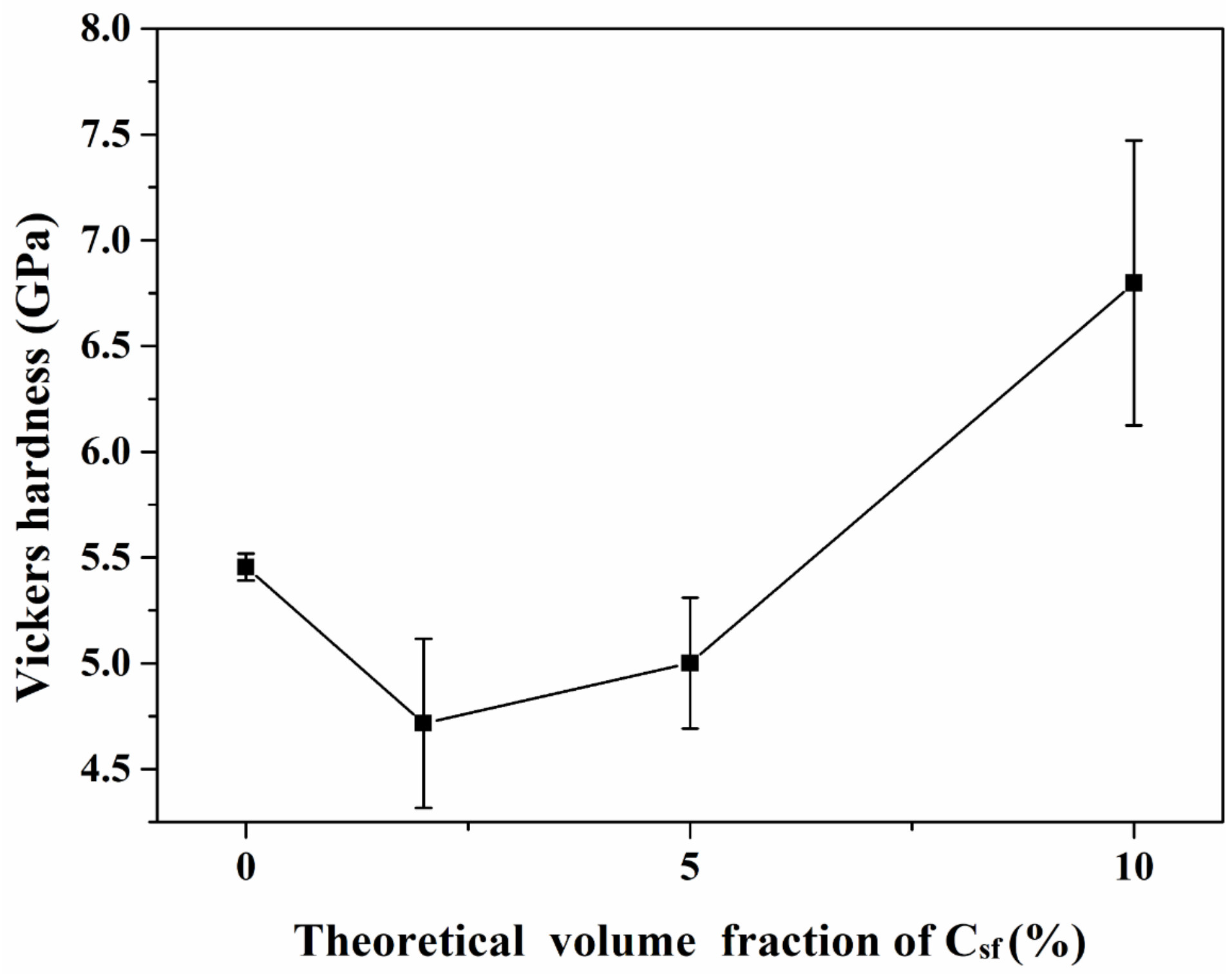

Figure 5

The dependence of Vickers hardness of the as-prepared Csf/Ti3SiC2 composites on the content of Csf. 


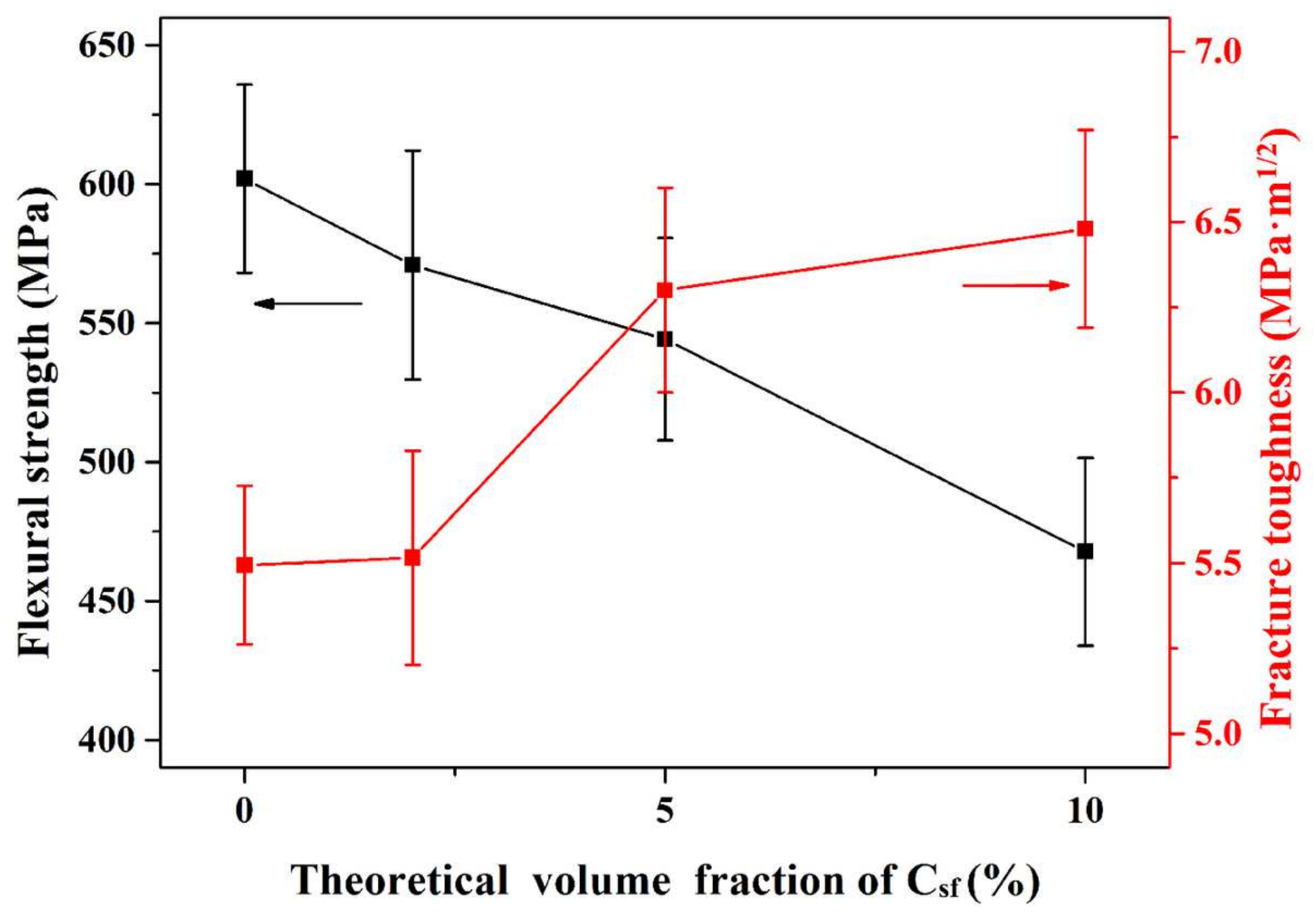

Figure 6

The dependence of flexural strength and fracture toughness of the as-prepared Csf/Ti3SiC2 composites on the content of Csf.

有

Figure 7

SEM micrographs of the fracture surfaces of (a) Ti3SiC2, (b) 2 Csf/Ti3SiC2, (c) 5 Csf/Ti3SiC2 and (d) 10 Csf/Ti3SiC2.

\section{Supplementary Files}

This is a list of supplementary files associated with this preprint. Click to download.

- Table.docx 